\title{
Microorganisms and cancer of the oral cavity
}

\author{
Kaoru Kusama $^{1 *}$, Harumi Inoue ${ }^{1}$, Yuji Miyazaki ${ }^{2}$, Kentaro Kikuchi ${ }^{1}$, Hideaki Sakashita ${ }^{3}$ and Kuniyasu Ochiai ${ }^{4}$ \\ ${ }^{1}$ Division of Pathology, Department of Diagnostic and Therapeutic Sciences, Meikai University School of Dentistry, Japan \\ ${ }^{2}$ Division of Basic Biology, Department of Oral Biology and Tissue Engineering, Meikai University School of Dentistry, Japan \\ ${ }^{3}$ Division of Oral and Maxillofacial Surgery, Department of Diagnostic and Therapeutic Sciences, Meikai University School of Dentistry, Japan \\ ${ }^{4}$ Nihon University School of Dentistry, Japan
}

\begin{abstract}
Numerous microorganisms, such as bacteria, viruses and fungi, inhabit the oral cavity, and it has been pointed out that poor oral hygiene and chronic periodontitis increase the risk of oral squamous cell carcinoma (OSCC). However, the molecular mechanism whereby the risk of OSCC is increased under such conditions has not yet been clarified. Microbes in the oral cavity may elicit both innate and acquired immune responses, resulting in the establishment of uncontrolled inflammation such as chronic periodontitis. Further microbial attack and various host-derived factors may subsequently contribute to events such as genetic and epigenetic alterations, inhibition of apoptosis, increased cell growth, promotion of invasion and metastasis, and lymphangiogenesis, thus linking the chronic inflammation to OSCC. Here we review the various factors involved in promoting the development and progression of OSCC. The facts suggest the importance of early prevention and treatment of chronic periodontitis to maintain oral health and prevent serious diseases such as OSCC.
\end{abstract}

\section{Introduction}

Most malignant neoplasms of the oral cavity are squamous cell carcinomas (SCCs) [1], and many factors are involved in the development of oral squamous cell carcinoma (OSCC) [2]. Although the primary causes of OSCC are tobacco and alcohol [1], the malignancy can occur even in individuals who do not smoke and drink [3], suggesting that other factors may also play a role. It has been pointed out that poor oral hygiene [4-8] and chronic periodontitis [9-12] may increase the risk of oral cancer. Numerous microorganisms, inhabiting in the oral region, such as bacteria, viruses and fungi, may affect the development and progression of OSCC. In this article, we describe the association of oral microorganisms and host-derived factors with OSCC, and also emphasize the importance of early prevention and treatment of chronic periodontitis for maintaining oral health and preventing lethal diseases such as OSCC.

\section{Dental caries and cancer}

Dental caries, one of the two major common diseases of the oral cavity, is characterized by destruction of enamel, dentin and cementum by commensal gram-positive bacteria. As the condition progresses, pulpitis and apical periodontitis develop jointly as sequelae. In extreme cases, patients may develop osteomyelitis and periostitis of the jaw, maxillary sinusitis, or Ludwig's angina, leading to potentially fatal sepsis or systemic inflammatory response syndrome (SIRS) (Figure 1). Therefore, early prevention and treatment of dental caries are clearly very important.

Tezal et al. [13] have reported an inverse association between dental caries and head and neck squamous cell carcinoma (HNSCC) and showed an inverse association, although the reason for this remains unknown and further studies are needed.

\section{Association between periodontal diseases and cancer}

Periodontal disease is the other major common disease of the oral cavity. Not only does it lead to destruction of periodontal tissue accompanied by tooth loss, but also it is associated with systemic conditions such as cardiovascular disease, adverse pregnancy outcomes, rheumatoid arthritis, diabetes, lung diseases, and cancer development and progression [9-12,14-24] (Figure 2). Therefore, treatment and prevention of periodontal disease are also a major concern.

There is a close association between periodontal disease and HNSCC [9-12]. It has been reported that each millimeter of alveolar bone loss is associated with a 5.23-fold increase in the risk of tongue cancer [9] and with more than a 4-fold increase in the risk of HNSCCs such as oropharyngeal and laryngeal carcinomas [10]. This association between periodontal disease and HNSCC is remarkable even in nonsmokers, making periodontal disease an independent risk factor for HNSCC [10]. In addition, it has been indicated that patients with periodontitis are more likely to develop poorly differentiated OSCC than those without [10], showing the association of periodontal disease with the development as well as progression of oral cancer.

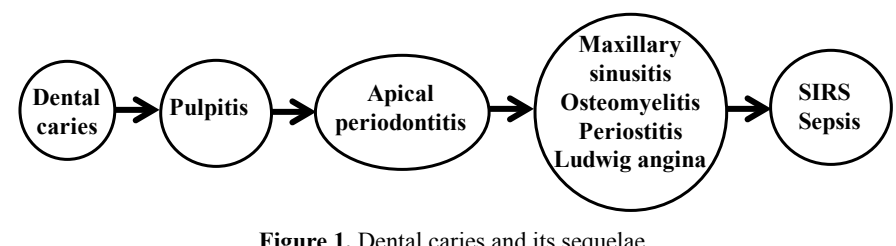

Figure 1. Dental caries and its sequelae.

Correspondence to: Kaoru Kusama, DDS, PhD, Division of Pathology, Department of Diagnostic \& Therapeutic Sciences, Meikai University School of Dentistry, 1-1 Keyakidai, Sakado, Saitama 350-0283, Japan, E-mail: kusama@dent.meikai.ac.jp

Key words: periodontitis, oral microorganism, oral bacteria, virus, oral squamous cell carcinoma

Received: June 06, 2016; Accepted: July 04, 2016; Published: July 08, 2016 


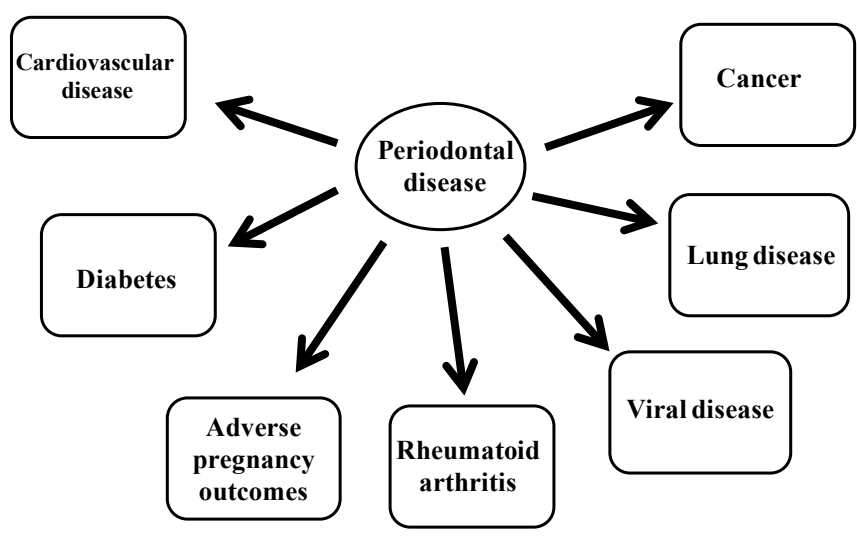

Figure 2. Systemic diseases associated with periodontal disease.

In addition to oral cancer, it has been shown that periodontal diseases are a risk factor for cancers of the oropharynx, larynx, lung, esophagus, pancreas, colon, rectum, kidney, and even hematopoietic organs [9-11,15-18,21-24].

However, all these findings have been revealed by epidemiological studies, and the actual mechanism responsible for the relationship between periodontal disease and the development and progression of human cancer remains to be determined.

\section{Involvement of oral bacteria in the development and progression of oral cancer}

Numerous microorganisms, such as bacteria, viruses and fungi, inhabit the oral region, and may be involved in the development and progression of oral cancer. Nagy et al. [25] reported that anaerobic bacterial species such as Veillonella, Fusobacterium, Prevotella, Porphyromonas, Actinomyces and Clostridium, and the aerobic species Haemophilus, Enterobacteriaceae and Streptococcus are detected much more frequently in oral cancer tissue than in normal oral mucosa. Candida albicans is also found in oral cancer tissue. Therefore, the question arises as to whether these microorganisms play a role in oral carcinogenesis.

It is well known that Helicobacter pylori is associated with chronic atrophic gastritis and the development of gastric cancer [26,27]. It has been reported that ectopic expression of activation-induced cytidine deaminase (AID), a gene-editing enzyme, in gastric mucosal epithelium due to infection with $H$. pylori which harbors a gene family called 'cag' pathogenicity island (cagPAI) might be a mechanism of mutational accumulation in gastric carcinogenesis [28]. Oral epithelial dysplasia and squamous cell carcinoma are also often associated with chronic inflammation. We have found ectopic expression of AID in oral moderate epithelial dysplasia and squamous cell carcinoma, and our in vitro study revealed that the expression of AID is enhanced by TNF- $\alpha$ via NF- $\kappa B$ activation in an oral cancer cell line (Figure 3) [29].

IL-8 plays an important role in the induction of inflammation and cell proliferation, and its secretion is induced in chronic gastritis by resulting from $H$. pylori infection. Chemokines including IL-8, and their receptors are considered to be related to the development and progression of various cancers [30]. Do certain oral bacteria play a role in the oral region similar to that of $H$. pylori in the stomach? It has been described that the enhanced expression of IL- 8 in oral cancer tissue and the higher concentration of serum IL- 8 in oral cancer patients relate to the prognosis [31]. Furthermore, IL-8 increases the number of CD163 positive M2 macrophages in the invasive front of oral cancer [31].
Fibroblasts are known to express hepatocyte growth factor (HGF) by infection of oral bacteria and inflammatory cytokines. C-MET is a receptor of HGF and dysregulation of its signaling is observed in oral carcinogenesis [32]. In addition, Actinobacillus actinomycetemcomitans, Escherichi coli LPS and TNF- $\alpha$ upregulate the production of CCL20 in oral cancer cell lines, suggesting that CCL20 contributes to the oral immunoresponse to bacterial infection and is involved in the growth of OSCC [33]. These findings indicate that oral bacteria may be related directly or indirectly to the promotion of cell proliferation.

Oral bacteria are detected much more frequently on the surface of primary oral cancer tissue and in the metastatic lymph nodes, in comparison with normal oral mucosa and non-metastatic lymph nodes $[34,35]$. Oral bacteria may invade through areas of tissue surface destruction due to oral cancer and flow into the cervical lymph nodes, suggesting a contribution of oral bacteria to progression of oral cancer. In fact, $P$. gingivalis is able to invade gingival epithelial cells and survive within them [36,37]. $P$. gingivalis is known to prevent apoptosis of gingival epithelial cells through various mechanisms, thus allowing itself to survive [38-41]. Furthermore, it has been reported that $P$. gingivalis promotes invasion of oral cancer through induction of proMMP9 and its activation [42]. It also stimulates secretion of IL-6 and IL-8 from oral epithelial cells [43] and inhibits the secretion of CXCL9, 10 and 11, resulting in promotion of angiogenesis and tumor growth [44]. Gallimidi et al. [45] have reported that chronic infection of $P$. gingivalis and F. nucleatum promotes chemically induced OSCC in mice, with augumentation of the IL-6-STAT3 signaling pathway. We have shown that butyric acid produced by $P$. gingivalis, known to be an inhibitor of histone deacetylase (HDAC), increases the expression of podoplanin in oral cancer cell lines and promotes cell migration [46] (Figure 4). Butyric acid may induce epigenetic changes in periodontal and surrounding tissues. Recently, Planello et al. [47] reported a significant overlap between altered DNA methylation patterns in chronic periodontitis and OSCC.

Streptococcus thermophiles and Streptococcus mitis hidden in deep periodontal pockets exhibit alcohol dehydrogenase activity and produce acetaldehyde, a known carcinogen derived from alcohol, suggesting one mechanism whereby pathogenesis of oral cancer may occur [48].

These findings suggest that periodontal disease is associated with a number of mechanisms of oral cancer development and progression, such as genetic and epigenetic alterations, inhibition of apoptosis,

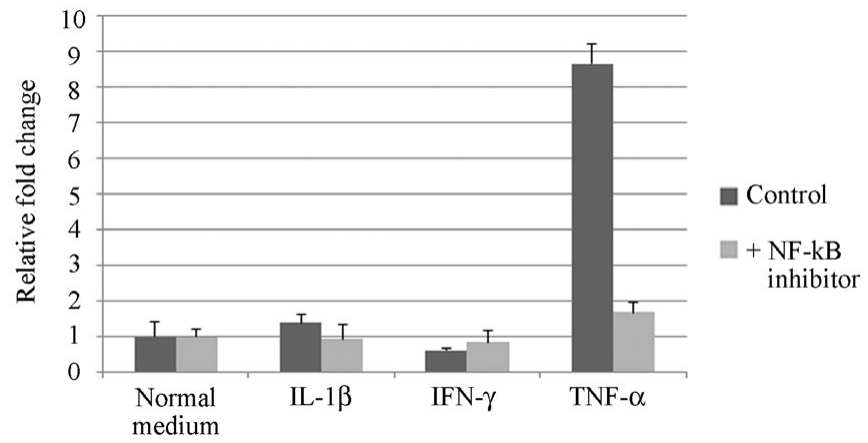

Figure 3. Effect of NF-kB activation by inflammatory cytokines on AID mRNA expression in HSC-2 cells[29]. After incubation of HSC-2 cells with inflammatory cytokines (interleukin- $1 \beta$, IL- $1 \beta$; interferon- $\gamma$, IFN- $\gamma$; tumor necrosis factor- $\alpha$, TNF- $\alpha$ ) with or without NF-kB inhibitor, RNAs were isolated from the cells. Real-time RT-PCR shows that NF-kB inhibitor attenuated AID mRNA expression stimulated by TNF- $\alpha$. Each column and bar represents the mean $\pm \mathrm{SD}$ of duplicate cultures. 
increased cell proliferation, promotion of invasion and metastasis, and angiogenesis.

\section{Involvement of viruses in the development and progression of oral cancer}

Various viruses such as Epstein-Barr virus (EBV), cytomegalovirus, herpes simplex virus type 1 and human papilloma virus (HPV) are known to reside in the oral cavity [49-53].

Patients with HPV-positive tongue cancer have more significant alveolar bone loss than HPV-negative patients [54], and chronic periodontitis tends to be more common in HPV-positive patients with primary SCC of the pharynx, larynx and mouth [55]. As is the case for cervical cancer, HPV has long been considered to be involved in OSCC [56-58]. However, recent studies [59-62] have revealed that HPV is much more commonly associated with cancers of the pharynx, larynx and tonsil, than with oral cancer.

Latent EBV infection is common in adults. In the oral regions, EBV is detectable in normal gingival epithelium and significantly detected in periodontal disease [63]. EBV-associated tumors are divided into those of the epithelial and lymphatic systems. Among epithelial tumors, nasopharyngeal carcinoma is the most common tumor associated with EBV [64]. EBV has also been associated with cancers of stomach, salivary gland, and breast [65-67]. We examined EBV latent infection genes and their expression in normal and dysplastic oral epithelium as well as in squamous cell carcinoma, and showed an association of EBV with the dysplasia-carcinoma sequence [68] (Figure 5). Although EBV is also associated with Burkitt's lymphoma and Hodgkin's lymphoma [69], EBV latent infection genes and their expression have been detected in immunodeficiency-related lymphoproliferative disorders (LPDs) such as methotrexate (MTX) and age-related LPDs [70-73]. LPDs of the oral cavity occur as intractable ulcers and are associated with severe periodontal disease [71-73] (Figure 6).

Hepatitis C virus (HCV) is known to induce hepatitis, cirrhosis, and hepatocellular carcinoma. It has been reported that HCV infection is related to the occurrence of oral lichen planus and oral cancer, although the pathogenetic mechanism is unknown [74-76].

A

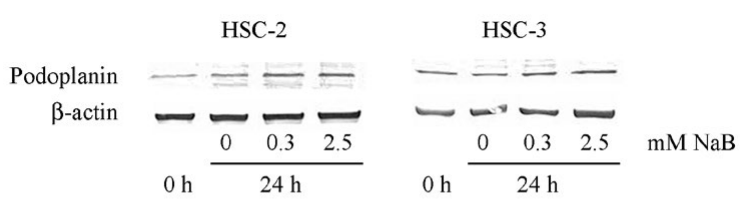

B
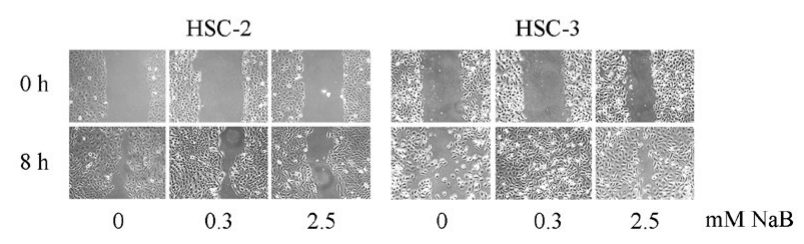

Figure 4. Effect of sodium butyrate $(\mathrm{NaB})$ on podoplanin expression and oral cancer cell migration [46].A: Podoplanin and $\beta$-actin expression studied by Western blot analysis after incubation of HSC-2 and HSC-3 cell lines with 0.3 or $2.5 \mathrm{mMNaB}$ for $24 \mathrm{~h}$. B: Scratch assay to study the effect of $\mathrm{NaB}$ on cell migration. The HSC-2 and HSC-3 cell lines were incubated in 12-well tissue culture slides with 0.3 or $2.5 \mathrm{mMNaB}$ for $8 \mathrm{~h}$. These findings indicate that $\mathrm{NaB}$ promotes podoplanin expression and migration of oral cancer cells.

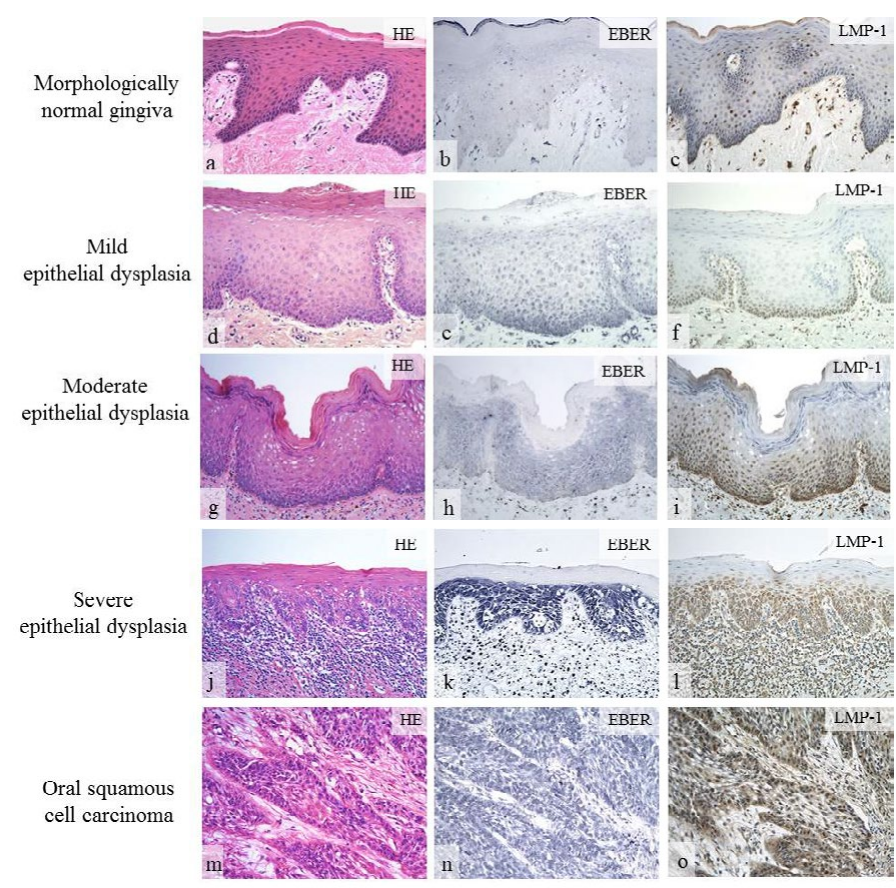

Figure 5. Expression of EBV latent infection gene in oral lesions [68]. In morphologically normal epithelium, expression of EBER and LMP-1 was negative or weakly positive (b, c). Expression of EBER and LMP-1 was greater in severe epithelial dysplasia $(k, 1)$ than in mild (e, f) to moderate $(\mathrm{h}, \mathrm{i})$ epithelial dysplasia. In oral squamous cell carcinoma, expression of EBER and LMP-1 was significantly positive (n, o).



Figure 6. Age-related lymphoproliferative disorder [72]. 3D-CT view showing irregular bone resorption surface, the so-called "moth-eaten" appearance, and remaining-teeth with severe periodontitis are noted (a). Bizarre giant cells with Hodgkin and Reed-Sternberglike appearance are evident in areas of granulomatous proliferation (b). The bizarre giant cells are positive for EBER (c) and LMP-1 (d).

\section{Interaction of oral bacteria and viruses in the development and progression of oral cancer}

It has been accepted that oral bacteria, typically $P$. gingivalis, and viruses interact, because the etiology of cancer due to bacteria alone cannot adequately explain a number of clinical aspects. It is known that a bacterial metabolite, butyric acid, inhibits the catalytic action of HDAC and induces transcription of silenced genes including HIV1 provirus, indicating that butyric acid-producing bacteria could be involved in AIDS progression by reactivating the latent HIV provirus and may contribute to the prevention of the AIDS development and 
transmission by eliminating such bacterial infection [77]. In addition to HIV-oral bacterial association, it has been reported that more EBV DNA is found in deeper periodontal pockets of in Japanese patients with chronic periodontitis [51]. A molecular study has revealed that $P$. gingivalis induces EBV reactivation via epigenetic change, and that butyric acid is responsible for this effect [50]. These findings suggest that periodontal disease is a risk factor for HIV or EBV reactivation in infected individuals [50,77].

However, it is not well understood how the interaction of oral bacteria and viruses is involved in the development and progression of cancer. One plausible possibility is the activation of a natural immune sensor, the toll-like receptor (TLR). TLR-2, -4 and -9 are activated by oral bacteria, whereas TLR- $3,-7,-8$, and -9 are activated by viruses [78]. The function of TLRs is complicated; they contribute to not only the promotion but also the prevention of oral carcinogenesis [7890]. A number of pathways are activated by microorganisms of the oral cavity, resulting in expression of various genes and secretion of many mediators into the extracellular environment. When periodontal tissue is exposed to continuous microbial stimuli or attack, innate as well as acquired immune responses are induced, and production of inflammatory mediators causes destructive changes, resulting in chronic periodontitis. Further chronic exposure to microbial and hostderived products modifies the microenvironment of the oral cavity and other distant tissues, linking uncontrolled inflammation to the development and progression of cancer characterized by various events, such as genetic and epigenetic alterations, enhanced cell proliferation, inhibition of apoptosis, lymphangiogenesis, and promotion of invasion and metastasis.

\section{Conclusion}

Poor oral hygiene and chronic periodontitis increase the risk of OSCC. Microbial infections in the oral cavity may induce innate and acquired immune responses, resulting in the establishment of uncontrolled chronic inflammation manifested as chronic periodontitis. Further microbial attack and various host-derived factors may contribute to events, such as genetic and epigenetic alterations, inhibition of apoptosis, increased cell growth, promotion of invasion and metastasis, and lymphangiogenesis, linking the chronic inflammation to OSCC. Therefore, early prevention and treatment of chronic periodontitis are extremely important for maintenance of oral health and prevention of potentially lethal diseases, such as OSCC.

\section{References}

1. Johnson N, Franceschi S, Ferlay J, Ramadas K, Schmid S, et al. (2005) Squamous cell carcinoma. In: Barnes L, Eveson JW, Reichart P, Sidransky D. WHO Classification of Tumours, Pathology \& Genetics, Head and Neck Tumours. Leon, IARC press, Lyon: 168-175.

2. La Vecchia C, Tavani A, Franceschi S, Levi F, Corrao G, et al. (1997) Epidemiology and prevention of oral cancer. Oral Oncol 33: 302-312. [Crossref]

3. Llewellyn CD, Johnson NW, Warnakulasuriya KA (2004) Risk factors for oral cancer in newly diagnosed patients aged 45 years and younger: a case-control study in Southern England. J Oral Pathol Med 33: 525-532. [Crossref]

4. Marshall JR, Graham S, Haughey BP, Shedd D, O'Shea R, et al. (1992) Smoking, alcohol, dentition and diet in the epidemiology of oral cancer. Eur J Cancer B Oral Oncol 28B: 9-15. [Crossref]

5. Maier H, Zöller J, Herrmann A, Kreiss M, Heller WD (1993) Dental status and oral hygiene in patients with head and neck cancer. Otolaryngol Head Neck Surg 108: 655661. [Crossref]

6. Bundgaard T, Wildt J, Frydenberg M, Elbrønd O, Nielsen JE (1995) Case-control study of squamous cell cancer of the oral cavity in Denmark. Cancer Causes Control 6: 5767. [Crossref]
7. Velly AM, Franco EL, Schlecht N, Pintos J, Kowalski LP, et al. (1998) Relationship between dental factors and risk of upper aerodigestive tract cancer. Oral Oncol 34: 284-291. [Crossref]

8. Rosenquist K, Wennerberg J, Schldt EB, Bladström A, Göran Hannson B, et al (2005) Oral status, oral infections and some lifestyle factors as risk factors for oral and oropharyngeal squamous cell carcinoma. A population-based case-control study in southern Sweden. Acta Otolaryngol 125: 1327-1336. [Crossref]

9. Tezal M, Sullivan MA, Reid ME, Marshall JR, Hyland A, et al. (2007) Chronic periodontitis and the risk of tongue cancer. Arch Otolaryngol Head Neck Surg 133: 450-454. [Crossref]

10. Tezal M, Sullivan MA, Hyland A, Marshall JR, Stoler D, et al. (2009) Chronic periodontitis and the incidence of head and neck squamous cell carcinoma. Cancer Epidemiol Biomarkers Prev 18: 2406-2412. [Crossref]

11. Meyer MS, Joshipura K, Giovannucci E, Michaud DS (2008) A review of the relationship between tooth loss, periodontal disease, and cancer. Cancer Causes Control 19: 895-907. [Crossref]

12. Krüger M, Hansen T, Kasaj A, Moergel M (2013) The Correlation between Chronic Periodontitis and Oral Cancer. Case Rep Dent 2013: 262410. [Crossref]

13. Tezal M, Scannapieco FA, Wactawski-Wende J, Meurman JH, Marshall JR, et al (2013) Dental caries and head and neck cancers. JAMA Otolaryngol Head Neck Surg 139: 1054-1060. [Crossref]

14. Lalla E, Papapanou PN (2011) Diabetes mellitus and periodontitis: a tale of two common interrelated diseases. Nat Rev Endocrinol 7: 738-748. [Crossref]

15. Han YW, Wang X (2013) Mobile microbiome: oral bacteria in extra-oral infections and inflammation. J Dent Res 92: 485-491. [Crossref]

16. Ide M, Papapanou PN (2013) Epidemiology of association between maternal periodontal disease and adverse pregnancy outcomes--systematic review. J Periodontol 84: S181-194. [Crossref]

17. Linden GJ, Lyons A, Scannapieco FA (2013) Periodontal systemic associations: review of the evidence. J Periodontol 84: S8-19 [Crossref]

18. Schenken HA, Loos BG (2013) Inflammatory mechanisms linking periodontal diseases to cardiovascular diseases. J Periodontol 84: S51-69. [Crossref]

19. Han YW, Houcken W, Loos BG, Schenkein HA, Tezal M (2014) Periodontal disease, atherosclerosis, adverse pregnancy outcomes, and head-and-neck cancer. Adv Dent Res 26: 47-55. [Crossref]

20. Hajishengallis G (2015) Periodontitis: from microbial immune subversion to systemic inflammation. Nat Rev Immunol 15: 30-44. [Crossref]

21. Michaud DS, Liu Y, Meyer M, Giovannucci E, Joshipura K (2008) Periodontal disease, tooth loss, and cancer risk in male health professionals: a prospective cohort study. Lancet Oncol 9: 550-558. [Crossref]

22. Abnet CC, Kamangar F, Islami F, Nasrollahzadeh D, Brennan P, et al. (2008) Tooth loss and lack of regular oral hygiene are associated with higher risk of esophageal squamous cell carcinoma. Cancer Epidemiol Biomarkers Prev 17: 3062-3068. [Crossref]

23. Fitzpatrick SG, Katz J (2010) The association between periodontal disease and cancer: a review of the literature. J Dent 38: 83-95. [Crossref]

24. Mai X, LaMonte MJ, Hovey KM, Nwizu N, Freudenheim JL, et al. (2014) History of periodontal disease diagnosis and lung cancer incidence in the Women's Health Initiative Observational Study. Cancer Causes Control 25: 1045-1053. [Crossref]

25. Nagy KN, Sonkodi I, Szöke I, Nagy E, Newman HN (1998) The microflora associated with human oral carcinomas. Oral Oncol 34: 304-308. [Crossref]

26. O'Mahony R, Vaira D, Holton J, Basset C (2004) Helicobacter pylori: current status and future prospects. Sci Prog 87: 269-296. [Crossref]

27. Houghton J, Wang TC (2005) Helicobacter pylori and gastric cancer: a new paradigm for inflammation-associated epithelial cancers. Gastroenterology 128: 1567-1578. [Crossref]

28. Matsumoto Y, Marusawa H, Kinoshita K, Endo Y, Kou T, et al. (2007) Helicobacter pylori infection triggers aberrant expression of activation-induced cytidine deaminase in gastric epithelium. Nat Med 13: 470-476. [Crossref]

29. Miyazaki Y, Fujinami M, Inoue H, Kikuchi K, Ide F, et al. (2013) Expression of activation-induced cytidine deaminase in oral epithelial dysplasia and oral squamous cell carcinoma. J Oral Sci 55: 293-299. [Crossref] 
30. Balkwill F (2004) Cancer and the chemokine network. Nat Rev Cancer 4: 540-550. [Crossref]

31. Fujita Y, Okamoto M, Goda H, Tano T, Nakashiro K, et al. (2014) Prognostic significance of interleukin-8 and CD163-positive cell-infiltration in tumor tissues in patients with oral squamous cell carcinoma. PLoS One 9: e110378. [Crossref]

32. Ohnishi T, Daikuhara Y (2003) Hepatocyte growth factor/scatter factor in development, inflammation and carcinogenesis: its expression and role in oral tissues. Arch Oral Biol 48: 797-804. [Crossref]

33. Abiko Y, Nishimura M, Kusano K, Nakashima K, Okumura K, et al. (2003) Expression of MIP-3alpha/CCL20, a macrophage inflammatory protein in oral squamous cell carcinoma. Arch Oral Biol 48: 171-175. [Crossref]

34. Sakamoto H, Sasaki J, Nord CE (1999) Association between bacterial colonization on the tumor, bacterial translocation to the cervical lymph nodes and subsequent postoperative infection in patients with oral cancer. Clin Microbiol Infect 5: 612-616. [Crossref]

35. Sakamoto H, Naito H, Ohta Y, Tanakna R, Maeda N, et al. (1999) Isolation of bacteria from cervical lymph nodes in patients with oral cancer. Arch Oral Biol 44: 789-793. [Crossref]

36. He J, Miyazaki H, Anaya C, Yu F, Yeudall WA, et al. (2006) Role of Porphyromonas gingivalis $\mathrm{FeoB} 2$ in metal uptake and oxidative stress protection. Infect Immun 74: 4214-4223. [Crossref]

37. Yilmaz O (2008) The chronicles of Porphyromonas gingivalis: the microbium, the human oral epithelium and their interplay. Microbiology 154: 2897-2903. [Crossref]

38. Yilmaz O, Jungas T, Verbeke P, Ojcius DM (2004) Activation of the phosphatidylinositol 3-kinase/Akt pathway contributes to survival of primary epithelial cells infected with the periodontal pathogen Porphyromonas gingivalis. Infect Immun 72: 3743-3751. [Crossref]

39. Mao S, Park Y, Hasegawa Y, Tribble GD, James CE, et al. (2007) Intrinsic apoptotic pathways of gingival epithelial cells modulated by Porphyromonas gingivalis. Cell Microbiol 9: 1997-2007. [Crossref]

40. Yao L, Jermanus C, Barbetta B, Choi C, Verbeke P, et al. (2010) Porphyromonas gingivalis infection sequesters pro-apoptotic Bad through Akt in primary gingival epithelial cells. Mol Oral Microbiol 25: 89-101. [Crossref]

41. Moffatt CE, Lamont RJ (2011) Porphyromonas gingivalis induction of microRNA-203 expression controls suppressor of cytokine signaling 3 in gingival epithelial cells. Infect Immun 79: 2632-2637. [Crossref]

42. Inaba H, Sugita H, Kuboniwa M, Iwai S, Hamada M, et al. (2014) Porphyromonas gingivalis promotes invasion of oral squamous cell carcinoma through induction of proMMP9 and its activation. Cell Microbiol 16: 131-145. [Crossref]

43. Yee M, Kim S, Sethi P, Duzgunes N, Konopka K (2014) Porphyromonas gingivalis stimulates IL-6 and IL-8 secretion in GMSM-K, HSC-3 and H413 oral epithelial cells. Anaerobe 28: 62-67. [Crossref]

44. Jauregui CE, Wang Q, Wright CJ, Takeuchi H, Uriarte SM, et al. (2013) Suppression of T-cell chemokines by Porphyromonas gingivalis. Infect Immun 81: 2288-2295. [Crossref]

45. Gallimidi AB, Fischman S, Revach B, Bulvik R, Maliutina A, et al. (2015) Periodontal pathgens Porphyromonas gingivalis and Fusobacterium nucleatum promote tumor progression in an oral-specific chemical carcinogenesis model. Oncotarget 6: 2261322623. [Crossref]

46. Miyazaki Y, Kikuchi K, González-Alva P, Inoue H, Noguchi Y, et al. (2010) Association of butyric acid produced by periodontopathic bacteria with progression of oral cancer. $J$ Cancer Sci Ther 2: 26-32.

47. Planello AC, Singhania R, Kron KJ, Bailey SD, Roulois D, et al. (2016) Pre-neoplastic epigenetic disruption of transcriptional enhancer in chronic inflammation. Oncotarget 7: 15772-15786. [Crossref]

48. Kurkivuori J, Salaspuro V, Kaihovaara P, Kari K, Rautemaa R, et al. (2007) Acetaldehyde production from ethanol by oral streptococci. Oral Oncol 43: 181-186. [Crossref]

49. Contreras A, Nowzari H, Slots J (2000) Herpesviruses in periodontal pocket and gingival tissue specimens. Oral Microbiol Immunol 15: 15-18. [Crossref]

50. Imai K, Inoue H, Tamura M, Cueno ME, Inoue H, et al. (2012) The periodontal pathogen Porphyromonas gingivalis induces the Epstein-Barr virus lytic switch transactivator ZEBRA by histone modification. Biochimie 94: 839-846. [Crossref]

51. Kato A, Imai K, Ochiai K, Ogata Y (2013) Higher prevalence of Epstein-Barr virus
DNA in deeper periodontal pockets of chronic periodontitis in Japanese patients. PLoS One 8: e71990. [Crossref]

52. Kubar A, Saygun I, Ozdemir A, Yapar M, Slots J (2005) Real-time polymerase chain reaction quantification of human cytomegalovirus and Epstein-Barr virus in periodontal pockets and the adjacent gingiva of periodontitis lesions. J Periodontal Res 40: 97-104 [Crossref]

53. Slots J (2010) Human viruses in periodontitis. Periodontol 2000 53: 89-110. [Crossref]

54. Tezal M, Sullivan Nasca M, Stoler DL, Melendy T, Hyland A, et al. (2009) Chronic periodontitis-human papillomavirus synergy in base of tongue cancers. Arch Otolaryngol Head Neck Surg 135: 391-396. [Crossref]

55. Tezal M, Scannapieco FA, Wactawski-Wende J, Hyland A, Marshall JR, et al. (2012) Local inflammation and human papillomavirus status of head and neck cancers. Arch Otolaryngol Head Neck Surg 138: 669-675. [Crossref]

56. Adler-Storthz K, Newland JR, Tessin BA, Yeudall WA, Shillitoe EJ (1986) Human papillomavirus type 2 DNA in oral verrucous carcinoma. J Oral Pathol 15: 472-475. [Crossref]

57. Yeudall WA (1992) Human papillomaviruses and oral neoplasia. Eur J Cancer B Oral Oncol 28B: 61-66. [Crossref]

58. Sugerman PB, Shillitoe EJ (1997) The high risk human papillomaviruses and oral cancer: evidence for and against a causal relationship. Oral Dis 3: 130-147. [Crossref]

59. Snijders PJ, Cromme FV, van den Brule AJ, Schrijnemakers HF, Snow GB, et al. (1992) Prevalence and expression of human papillomavirus in tonsillar carcinomas, indicating a possible viral etiology. Int J Cancer 51: 845-850. [Crossref]

60. Wilczynski SP, Lin BT, Xie Y, Paz IB (1998) Detection of human papillomavirus DNA and oncoprotein overexpression are associated with distinct morphological patterns of tonsillar squamous cell carcinoma. Am J Pathol 152: 145-156. [Crossref]

61. Gillison ML, Koch WM, Capone RB, Spafford M, Westra WH, et al. (2000) Evidence for a causal association between human papillomavirus and a subset of head and neck cancers. J Natl Cancer Inst 92: 709-720. [Crossref]

62. Kreimer AR, Clifford GM, Boyle P, Franceschi S (2005) Human papillomavirus types in head and neck squamous cell carcinomas worldwide: a systematic review. Cancer Epidemiol Biomarkers Prev 14: 467-475. [Crossref]

63. Vincent-Bugnas S, Vitale S, Mouline CC, Khaali W, Charbit Y, et al. (2013) EBV infection is common in gingival epithelial cells of the periodontium and worsens during chronic periodontitis. PLoS One 8: e80336. [Crossref]

64. Chan JKC, Bray F, McCarron P, Foo W, Lee AWM, et al. (2005) Nasopharyngeal carcinoma, In: Barnes L, Eveson JW, Reichart P, Sidransky D: World Health Organization Classification of Tumours, Pathology and Genetics of Head and Neck Tumours, International Agency for Research on Cancer, IARC Press, Lyon: 85-97.

65. Dong M, Wang HY, Zhao XX, Chen JN, Zhang YW, et al. (2016) Expression and prognostic roles of PIK3CA, JAK2, PD-L1, and PD-L2 in Epstein-Barr virusassociated gastric carcinoma. Hum Pathol 53: 25-34. [Crossref]

66. Hamilton-Dutoit SJ, Therkidsen MH, Neilsen NH, Jensen H, Hansen JP, et al (1991) Undifferentiated carcinoma of the salivary gland in Greenlandic Eskimos: demonstration of Epstein-Barr virus DNA by in situ nucleic acid hybridization. Hum Pathol 22: 811-815. [Crossref]

67. Khabaz MN (2013) Association of Epstein-Barr virus infection and breast carcinoma Arch Med Sci 9: 745-751. [Crossref]

68. Kikuchi K, Noguchi Y, Garcia-Nino de Rivera M W, Hoshino M, Sakashita H, et al (2016) Detection of Epstein-Barr virus genome and latent infection gene expression in normal epithelia, epithelial dysplasia, and squamous cell carcinoma of the oral cavity. Tumour Biol 37: 3389-3404. [Crossref]

69. Houldcroft CJ, Kellam P (2015) Host genetics of Epstein-Barr virus infection, latency and disease. Rev Med Virol 25: 71-84. [Crossref]

70. Dojcinov SD, Venkataraman G, Raffeld M, Pittaluga S, Jaffe ES (2010) EBV positive mucocutaneous ulcer--a study of 26 cases associated with various sources of immunosuppression. Am J Surg Pathol 34: 405-417. [Crossref]

71. Kikuchi K, Miyazaki Y, Tanaka A, Shigematsu H, Kojima M, et al. (2010) Methotrexaterelated Epstein-Barr virus (EBV)-associated lymphoproliferative disorder — so-called "Hodgkin-like lesion" - of the oral cavity in a patient with rheumatoid arthritis. Head Neck Pathol 4: 305-311. [Crossref]

72. Kikuchi K, Fukunaga S, Inoue H, Miyazaki Y, Kojima M, et al. (2013) A case of agerelated Epstein-Barr virus (EBV)-associated B cell lymphoproliferative disorder, so- 
called polymorphous subtype, of the mandible, with a review of the literature. Head Neck Pathol 7: 178-187. [Crossref]

73. Kikuchi K, Ishige T, Ide F, Ito Y, Saito I, et al. (2015) Overexpression of activationinduced cytidine deaminase in MTX- and age-related Epstein-Barr virus-associated B-cell lymphoproliferative disorders of the head and neck. J Oncol. [Crossref]

74. Nagao Y, Sata M, Noguchi S, Seno'o T, Kinoshita M, et al. (2000) Detection of hepatitis C virus RNA in oral lichen planus and oral cancer tissues. J Oral Pathol Med 29: 259266. [Crossref]

75. Alavian SM, Mahboobi N, Mahboobi N, Karayiannis P (2013) Oral conditions associated with hepatitis C virus infection. Saudi J Gastroenterol 19: 245-251. [Crossref]

76. Nagao Y, Sata M (2013) Oral verrucous carcinoma arising from lichen planus and esophageal squamous cell carcinoma in a patient with hepatitis $\mathrm{C}$ virus-related liver cirrhosis-hyperinsulinemia and malignant transformation: A case report. Biomed Rep 1: 53-56. [Crossref]

77. Imai K, Yamada K, Tamura M, Ochiai K, Okamoto T (2012) Reactivation of laten HIV-1 by a wide variety of butyric acid-producing bacteria. Cell Mol Life Sci 69: 25832592. [Crossref]

78. Sahingur SE, Yeudall WA (2015) Chemokine function in periodontal disease and oral cavity cancer. Front Immunol 6: 214. [Crossref]

79. Min R, Zun Z, Siyi L, Wenjun Y, Lizheng W, et al. (2011) Increased expression of Tolllike receptor-9 has close relation with tumour cell proliferation in oral squamous cell carcinoma. Arch Oral Biol 56: 877-884. [Crossref]

80. Chuang HC, Huang CC, Chien CY, Chuang JH (2012) Toll-like receptor 3-mediated tumor invasion in head and neck cancer. Oral Oncol 48: 226-232. [Crossref]

81. Min R, Siyi L, Wenjun Y, Shengwen L, Ow A, et al. (2012) Toll-like receptor-9 agonists increase cyclin D1 expression partly through activation of activator protein-1 in human oral squamous cell carcinoma cells. Cancer Sci 103: 1938-1945. [Crossref]
82. Ahn MY, Kwon SM, Cheong HH, Park JH, Lee J, et al. (2012) Toll-like receptor 7 agonist, imiquimod, inhibits oral squamous carcinoma cells through apoptosis and necrosis. J Oral Pathol Med 41: 540-546. [Crossref]

83. Kotrashetti VS, Nayak R, Bhat K, Hosmani J, Somannavar P (2013) Immunohistochemical expression of TLR4 and TLR9 in various grades of ora epithelial dysplasia and squamous cell carcinoma, and their roles in tumor progression: a pilot study. Biotech Histochem 88: 311-322. [Crossref]

84. Zeljic K, Supic G, Jovic N, Kozomara R, Brankovic-Magic M, et al. (2014) Association of TLR2, TLR3, TLR4 and CD14 genes polymorphisms with oral cancer risk and survival. Oral Dis 20: 416-424. [Crossref]

85. Ruan M, Thorn K, Liu S, Li S, Yang W, et al. (2014) The secretion of IL-6 by CpGODN-treated cancer cells promotes T-cell immune responses partly through the TLR-9, AP-1 pathway in oral squamous cell carcinoma. Int J Oncol 44: 2103-2110. [Crossref]

86. Omar AA, Korvala J, Haglund C, Virolainen S, Häyry V, et al. (2015) Toll-like receptors -4 and -5 in oral and cutaneous squamous cell carcinomas. J Oral Pathol Med 44: 258-265. [Crossref]

87. Ni YH, Ding L, Zhang DY, Hou YY, Huang X, et al. (2015) Distinct expression patterns of Toll-like receptor 7 in tumour cells and fibroblast-like cells in oral squamous cell carcinoma. Histopathology 67: 730-739. [Crossref]

88. Mäkinen LK, Ahmed A, Hagström J, et al. (2016) Toll-like receptors 2, 4, and 9 in primary, metastasized, and recurrent oral tongue squamous cell carcinomas. J Oral Pathol Med 45: 338-345. [Crossref]

89. Koga-Yamakawa E, Dovedi SJ, Murata M, Matsui H, Leishman AJ, et al. (2013) Intratracheal and oral administration of SM-276001: a selective TLR7 agonist, leads to antitumor efficacy in primary and metastatic models of cancer. Int $J$ Cancer 132 580-590. [Crossref]

90. He Z, Huang X, Ni Y, Shi P, Wang Z, et al. (2014) Functional toll-like receptor 3 expressed by oral squamous cell carcinoma induced cell apoptosis and decreased migration. Oral Surg Oral Med Oral Pathol Oral Radiol 118: 92-100. [Crossref]

Copyright: (C2016 Kusama K. This is an open-access article distributed under the terms of the Creative Commons Attribution License, which permits unrestricted use, distribution, and reproduction in any medium, provided the original author and source are credited. 